ativo fixo, quando se faz o quadro econbimico total para fins de avaliação do retorno ou do custo. Mesmo assim, acredito que os capítulos 12 e 13 são os melhores do ponto de vista prático. Eles mostram o cálculo por indices de despesas e outros métodos determinantes da filosofia de armazenagem.

Outro uso de matemática está no capítulo 4. onde filas de espera e grau de atendimento (serviço) são mostrados de maneira clara (pág. 110), mas sem deduçao, o que seria supérfluo neste livro.

Os capítulos do livro são:

1) Introduçào à Armazenagem

2) Logistica e Distribuição Física

3) Os Materiais e os Inventários

4) Planejamento Fisico do Armazẻm

5) Recebimento e Expedição

6) Sistemas de Estocagem

7) Sistemas de Localização do Estoque

8) Separação de Pedidos

9) Layout de Armazém

10) Computadores na Arrnazenagem

11) Layout do Armazém com Auxilio do Computador

12) Dimensionamento de Espaços

13) Custos de Armazenagem

14) Manutençäo e Treinamento

15) Avaliação de Alternativas e Auditoria

Reinaldo de Moura é um dos maiores especialistas da área de logística no Brasil. Tem experiência internacional, principalmente no Japão e lidera eficiente grupo de consultores no IMAM, do qual é presidente. A prática do autor é que é transmitida da melhor maneira nos inúmeros pontos onde tal é necessârio, nas instalaçoos e equipamentos; estudados, planejados e instalados.

Como livro-texto, hat necessidade de complementação, em cursos de pós-graduaçăo, principalmente.

Em cursos de extensão, basta o livro acomparhado de filmes ou $\mathrm{VC}$, ou ainda catálogos e slides. De qualquer maneira, a alta importância da contribuição de Reinaldo de Moura não pode ser subestimada, pois escrever sozinho livros de 350 páginas no Brasil é uma operação sem retorno imediato. O livro, portanto, pode ser lido com proveito por todos que usam a logística no dia a dia, mesmo sem esse nome explicito. A definição de logística se encontra na página 27 do livro. Os usuários devem compreender os grupos de técnicos e executivos de transportes, compras, almoxarifados, armazéns, mercadologia e produção. Ótima apresentação gráfica. Lembro-me de ter resenhado o livro sobre sistemas e técnicas de movimentação e armazenagem hă bem uns 10 anos, do mesmo autor, e considerado o trabalho dele brilhante. Não modifiquei minha opinião, apôs leitura deste volume e adoção dele em alguns cursos.

\section{RIDING THE WAVES OF CHANGE - DEVELOPING MANAGERIAL COMPETENCIES FOR A TURBULENT WORLD}

\author{
GARETH MORGAN \\ San Francisco, Jossey-Bass Publishers, 1988.
}

\section{Por Jose Roberto Ferro}

Professor Assistente do Departamento de Engenharia de Produçäo da Universidade Federal de Sazo Carlos e Visiting Scholar do Massachusetts Institute of Technology, Cambridge, USA.

A mais recente contribuição de Gareth Morgan segue uma coleção de obras de excelente qualidade em teoria organizacional. Såo bastante conhecidos e reconhecidos seus livros anteriores. Escreveu com Gibson Burrell Sociological Paradigms and Organizational Analysis, publicado em 1979, um dos mais interessantes e completos trabalhos discorrendo sobre o impacto das diferentes perspectivas teóricas em ciências sociais sobre a teoria organizacional. Posteriormente, editou, em 1983, uma valiosa coletânea de textos, Beyond Method tratando das diferentes metodologias em teoria organizacional, com particular ênfase em metodologias qualitativas. Em 1986, publica Images of Organizations, um excelente livro texto tratando dos principais desenvolvimentos teóricos ocorridos nas últimas duas décadas. Alêm disso, Morgan produziu inúmeros artigos, muitos publicados na conhecida Administrative Sience Quarterly.

$O$ último livro de Morgan, Riding in the wawes of change, distingue-se dos outros por sua menor preocupaçăo com elaborações teóricas e por uma linguagem que o torna acessivel a um público muito mais amplo do que os anteriores, atingindo dessa vez "präticos" e "praticantes" com preocupações e demandas muito distintas do público essencialmente "acadêmico" anteriormente alvo das suas contribuiçōes. Assim, o autor está muito mais preocupado em desenvolver e disseminar sua pesquisa a partir das implicaçōes praticas que elas envolvem.

Essa obra foi elaborada a partir de projeto na Universidade de York, em Toronto, Canadá, onde o autor trabalha, a partir de recursos fornecidos pela Shell. A pesquisa envolveu executivos da alta administraçăo de empresas canadenses em um programa de aprendizado-açăo (action-learning), onde, além de se produzir um resultado original da pesquisa, tem-se como resultado adícional a contribuç̧âo para aqueles que estão diretamente envolvidos com o seu projeto. Procurou-se com- 
preender nesse projeto o impacto das principais mudanças ambientais no futuro desenvolvimento das organizaçōes.

A partir de um cenário preliminar construído pelos pesquisadores, descrevendo as principais mudanças que vêm ocorrendo no ambiente em que as organizaçōes estão inseridas, o projeto articulou pequenos grupos de executivos dos mais diferentes setores da economia canadense que se posicionaram sobre o modelo construído e sobre as competências gerenciais que serão necessárias para viver e sobreviver nesse mundo de constantes mudanças e turbulências.

Os principais tópicos do trabalho tratam dos itens seguintes, fundamentais nas organizaçōes do futuro:

a) leitura apropriada do ambiente. Uma das competências gerenciais fundamentais e a capacidade de ler $e$, se possível, antecipar o futuro. Merece particular atenção a ocorrencia de linhas de fratura (fracture lines) quando mudanças radicais podem ocorrer e dramaticamente alterar ofuturo da organização. Um dos exemplos que o autor fornece é o impacto dos sistemas Just-in-Time sobre o processo de administraçäo, quando a ênfase muda de um enfoque intraorganizacional para um enfoque interorganizacional, a administração passa a ser essencialmente uma atividade de coordenaçăo de redes de organizações, distribuindo controles e responsabilidades, aumentando a cooperação entre organizaçôes e possibilitando a emergência de uma produção em massa e "sob encomen$\mathrm{da}^{\prime \prime}$ ao mesmo tempo;

b) administração deve ser proativa. Mesmo em épocas difíceis, o administrador deve ser capaz de aproveitar oportunidades, tomar iniciativas, desenvolver inovaçóes e assumir riscos capazes de reposicionar a organização constantemente;

c) necessidade de desenvolver uma visäo compartilhada. E fundamental que os membros da organizaçâo tenham um sentido comum de missão ou filosofia, capaz de guiar as açōes. Os líderes devem ser capazes de criar símbolos ao mesmo tempo em que, em si, se constituem em símbolos, sendo responsáveis pelo processo de desenvolvimento de valores, direção e responsabilidade compartilhados:

d) recursos humanos são fundamentais. $O$ desenvolvimento da potencialidade total dos indivíduos na organização através da criatividade, 60 nhecimento, informaçăo e responsabilidade, criando condições para o desenvolvimento de relações empáticas e cooperativas através de um processo constante de aprendizado, é um elemento decisivo nas organizações do futuro;

e) promoção da descentralização e auto-organização. As organizações grandes e burocráticas eśtão cedendo lugar as organizaçóes pequenas que, entretanto, sāo articuladas por uma fonte comum, exigindo um novo enfoque de administração, onde - controle tende a ser menos rígido e a ambigüidade tende a ser maior. Deve-se procurar um caminho intermediário entre controle e caos, e aprender a desenvolver os padröes de dependên. cia mútua;

f) utilizar as potencialidades das tecnologias de informação. Um dos fatores mais importantes na organizaçẫo moderna, as tecnologias de informaçäo trazem impactos de diversas ordens. Notam-se mudanças nas características dos produtos, tornando-os cada vez mais "inteligentes" e com múltiplos propósitos em ciclos de vida cada vez mais curtos. A organização do trabalho também

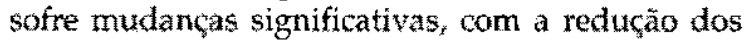
niveis hierárquicos e a possibilidade de democratizar as relaçôes de trabalho, reduzindo as distâncias entre o pensar e o fazer. Os usuários das novas tecnologias devem estar preparados tecnicamente, assim como os administradores devem ter desenvolvido uma mentalidade de aceitação da mudança, de modo a introduzir com sucesso as tecnologias. Há ainda um impacto significativo sobre os processos de tomada de decisăo, que podem ser mais rápidos.

Em seguida, o autor discute algumas particularidades do contexto canadense e conclui desenvolvendo as diretrizes gerais de um programa de desenvolvimento de competências para administradores, fomecendo tanto a temática a ser seguida, como também algumas formas de implementá-lo.

O livo merece ser lido,embora nada de excepcionalmente novo tenha sido dito. Para especialistas, pode não trazer muitas coisas novas e, em alguns casos, como, por exemplo, na discussão do impacto das tecnologias de informação, é muito simplista e determinista, esquecendo o impacto de diferentes culturas organizacionais sobre a utilização de tecnologias. $O$ trabalho é muito bem escrito. fácil de ler e faz uma excelente revisăo das tendências mais importantes das organizaçōes modernas. A utilização dos depoimentos dos executivos foi bem feita, mas os exemplos práticos poderiam ser usados mais freqüentemente e melhor explorados do que foram. Para aqueles que vivem o dia a dia das organizaçōes e têm que planejar o seu futuro ou ao menos se preocupar com ele, é uma leitura rica e flustrativa, mais bem fundamentada do que obras populares como In Search of Excellence de Peters e Waterman. 